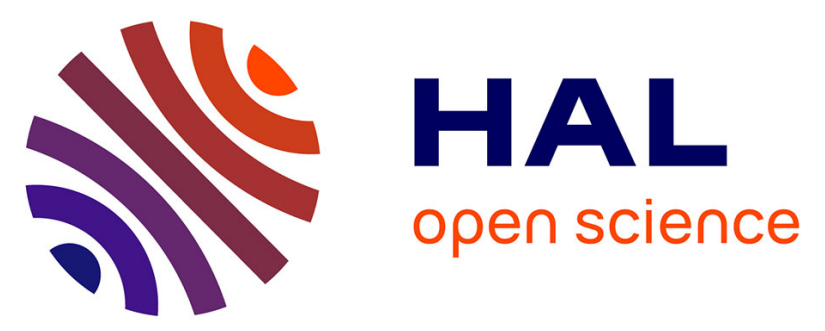

\title{
Red coloration of oysters along the French Atlantic coast during the 1998 winter season: implication of nanoplanktonic cryptophytes
}

A Pastoureaud, Christine Dupuy, M.J. Chretiennot-Dinet, François Lantoine, Pascale Loret

\section{To cite this version:}

A Pastoureaud, Christine Dupuy, M.J. Chretiennot-Dinet, François Lantoine, Pascale Loret. Red coloration of oysters along the French Atlantic coast during the 1998 winter season: implication of nanoplanktonic cryptophytes. Aquaculture, 2003, 10.1016/S0044-8486(03)00266-7 . hal-01248030

\section{HAL Id: hal-01248030 \\ https://hal.science/hal-01248030}

Submitted on 26 Dec 2016

HAL is a multi-disciplinary open access archive for the deposit and dissemination of scientific research documents, whether they are published or not. The documents may come from teaching and research institutions in France or abroad, or from public or private research centers.
L'archive ouverte pluridisciplinaire HAL, est destinée au dépôt et à la diffusion de documents scientifiques de niveau recherche, publiés ou non, émanant des établissements d'enseignement et de recherche français ou étrangers, des laboratoires publics ou privés. 


\title{
Red coloration of oysters along the French Atlantic coast during the 1998 winter season: implication of nanoplanktonic cryptophytes
}

\author{
A. Pastoureaud ${ }^{\mathrm{a}, *}$, C. Dupuy ${ }^{\mathrm{b}}$, M.J. Chrétiennot-Dinet ${ }^{\mathrm{c}}$, \\ F. Lantoine ${ }^{\mathrm{c}}$, P. Loret $^{\mathrm{d}}$ \\ a IFREMER-DEL, BP 171, 34203 Sète, France \\ ${ }^{\mathrm{b}}$ LBEM, EA 3168, Pôle Science, Université de La Rochelle, Av. Michel Crépeau, 17042 La Rochelle, France \\ ${ }^{\mathrm{c} O b s e r v a t o i r e ~ O c e ́ a n o l o g i q u e ~ d e ~ B a n y u l s, ~ U M R ~ 7621, ~ C N R S / I N S U / U n i v e r s i t e ́ ~ P a r i s ~ 6, ~ L a b o r a t o i r e ~ A r a g o, ~}$ \\ BP 44, 66651 Banyuls-sur-mer Cédex, France \\ ${ }^{\mathrm{d}}$ Department of Earth and Ocean Sciences, University of British Columbia, 6270 University Boulevard, \\ Vancouver, BC, Canada V6T $1 Z 4$
}

Received 9 May 2002; received in revised form 11 March 2003; accepted 17 March 2003

\begin{abstract}
During a 4-week experiment on oyster grazing in coastal ponds (claires) near La Rochelle (France), a red coloration was observed in the digestive gland of oysters. This pigmentation was attributed to an intensive grazing on cryptophyte nanoflagellates. Three different techniques led to this conclusion, mentioning for the first time free-living cryptophytes as responsible for such a phenomenon. Spectrofluorometry was used to demonstrate that the red coloration was due to the presence of a phycoerythrin, characteristic of cryptophytes. Microscopic observations and accessory pigments analyses in water ponds confirmed that the source of this pigment was of cryptomonadal origin. Oyster grazing on these algae is evidenced by large differences in alloxanthin concentrations and flagellate abundances between the two experimental ponds. The winter occurrence of this phenomenon is of importance for oyster commercialization and a short-term depuration is suggested to remove the undesirable pigmentation.
\end{abstract}

(C) 2003 Elsevier Science B.V. All rights reserved.

Keywords: Cryptophytes; Digestive gland; Oysters; Phycoerythrin; Aquaculture

* Corresponding author. Tel.: +33-4-99-57-32-80; fax: +33-4-99-57-32-96.

E-mail address: apastour@ifremer.fr (A. Pastoureaud). 


\section{Introduction}

The occurrence of red-coloured digestive gland in cultured molluscs is a well known phenomenon, already described for Crassostrea gigas (Hata and Hata, 1982 ; Hata et al., 1982a,b). According to these authors, the discoloration is due to the ingestion of the dinoflagellate Prorocentrum micans by the oysters. The pigment responsible for the red color is the water soluble peridinin-chlorophyll $a$-protein complex described by Prézelin and Haxo (1976).

The ciliate Mesodinium rubrum also induces a similar color in cultured bivalves (oysters, mussels or scallops) (Kat, 1984; Carver et al., 1996). It harbours a phycoerythrin containing chloroplast, whose origin is under discussion (Gustafson et al., 2000).

The macroscopic evidence of pigment accumulation in bivalves implies an intense grazing on the pigment-containing organism. This observation could be explained either by the fact that these organisms are predominant or that oysters preferentially select them among food particles present in the water. Particle selection in suspension feeders is well documented (Shumway et al., 1985; Ward et al., 1997) and it has been shown that several mechanisms are involved in this process.

Red coloration of oysters also occurs occasionally in French oyster farms along the Atlantic and Mediterranean coasts. Such a phenomenon was observed in December 1998 during an experimental study of the food-web in oyster ponds of the French Atlantic coast (Dupuy et al., 2000).

The present study reports on environmental conditions prevailing during this event, planktonic populations present in the ponds and pigment analyses. Although never associated to any toxic event, the presence of a red outflow under shell opening hampers oyster commercialization.

\section{Materials and methods}

The study was carried out in two experimental ponds (claires) near La Rochelle (French Atlantic coast, $46^{\circ} 9^{\prime} \mathrm{N}$ and $1^{\circ} 9^{\prime} \mathrm{W}$ ). The two experimental ponds were located side by side and had the same limited surface area $\left(200 \mathrm{~m}^{2}\right)$ and depth $(\sim 1 \mathrm{~m})$. They were supplied with coastal marine water via an inlet pipe connected to the sea during the period of spring tides. Seawater was confined for 4 weeks in the ponds, one without oysters considered as the control, the other with 20 oysters (mean dry weight: $1 \mathrm{~g}$ ) per square meter, a density usually used by oyster farmers.

Sampling strategy was performed as described by Dupuy et al. (2000): 12 subsurface samples were collected weekly, between 1400 and 1500 h, using a 2.5-1 "Van Doorn" bottle. Autotrophic and heterotrophic planktonic communities were studied by microscopy and HPLC pigment analysis.

The experimental site was equipped with a weather station to automatically record illumination, rainfall, temperature and salinity (see Begout-Anras, 1995).

Flagellates were fixed, stained and enumerated according to Haas (1982), Caron (1983) and Sherr et al. (1994) as modified by Dupuy et al. (1999). Samples were preserved with formaldehyde (final concentration 1\%). Each sample was concentrated to $10 \mathrm{ml}$ and stained 
by primulin $\left(50 \mu \mathrm{g} \mathrm{ml}^{-1}\right.$ final concentration). This method allows discrimination between autotrophic and heterotrophic flagellates without specific identification. In order to identify the flagellates at the species level, an aliquot was examined with a scanning electron microscope.

Samples were fixed with $4 \%$ formalin before being processed for scanning electron microscopy. Cells were centrifuged on a plastic cell culture coverslip (Thermanox) coated with L-polylysine for a better adhesion of material. Coverslips were critical point dried before mounted on stubs, coated with gold and examined in a Hitachi S 4500 scanning electron microscope in Perpignan, France.

Pigments were extracted in $2 \mathrm{ml}$ methanol $100 \%$ by crushing and stirring with a glass rod and sonicating for $30 \mathrm{~s}$. Vials were then stored for $1 \mathrm{~h}$ in the dark at $4{ }^{\circ} \mathrm{C}$. The extract
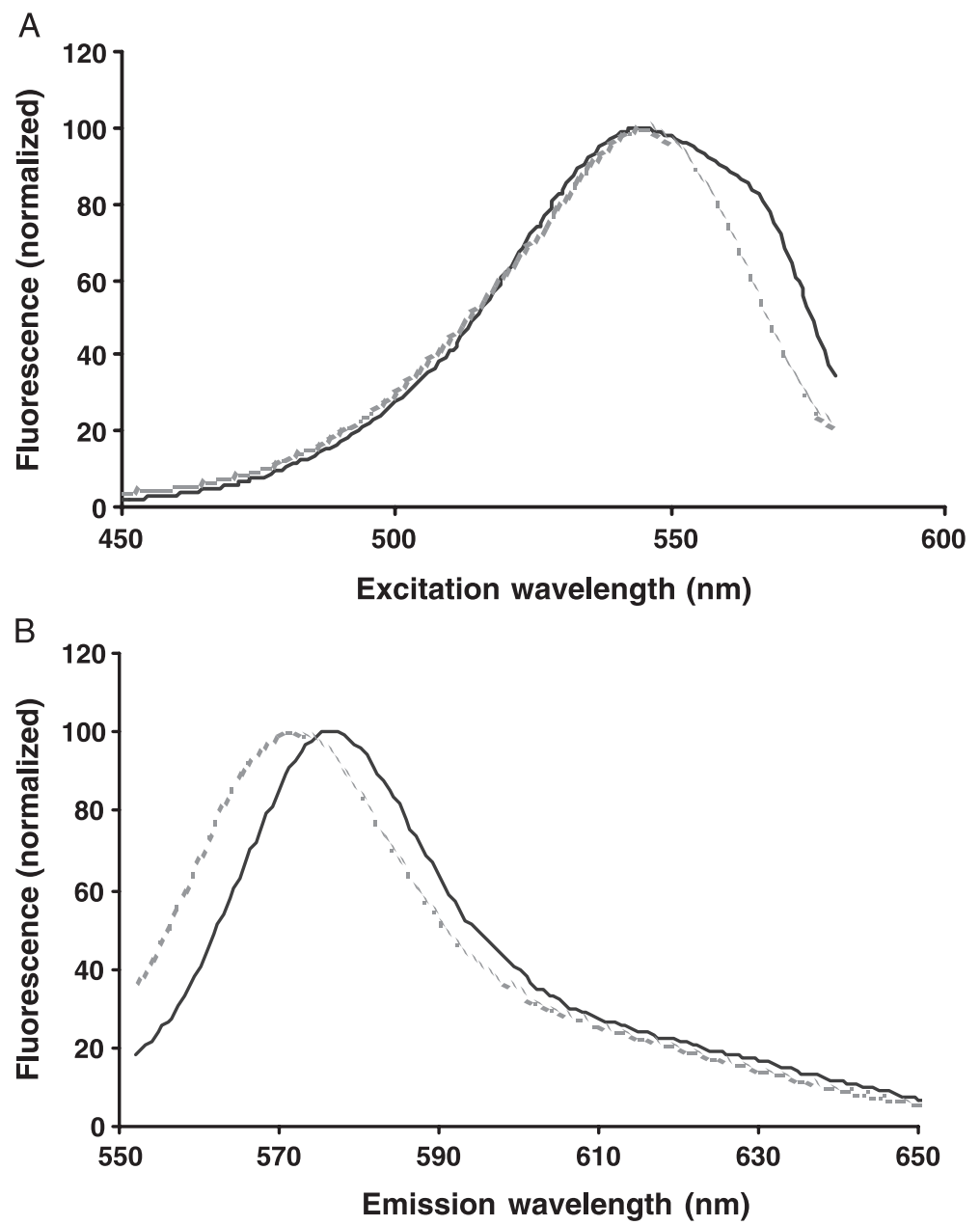

Fig. 1. Fluorescence excitation (A) and emission (B) spectra in phosphate buffer of the pigments extracted from the proximal (straight line) and distal (dashed line) part of oyster digestive tract. 
was filtered on a GF/F membrane and, just before injection, was diluted with ammonium acetate buffer $(0.5 \mathrm{M})$ to an $80 \%$ methanol concentration.

Chlorophylls and carotenoids were analysed by HPLC using the method described by Wright et al. (1991). The system consisted of a Kontron liquid chromatograph equipped with three HPLC 422 pumps, a diode array detector 440 and a spectrofluorometer SFM 25. The reverse phase column used was Allsphere ODS2, $25 \mathrm{~cm} \times 4.6 \mathrm{~mm}$ ID, $5 \mu \mathrm{m}$ particle size (Alltech). Pigments were identified by diode array spectroscopy during elution and quantified by injection of standard pigments.

Accessory pigments used as taxonomic markers were fucoxanthin for diatoms, peridinin for autotroph dinoflagellates, chlorophyll $b$ for green flagellates (chlorophytes and prasinophytes) and alloxanthin for cryptophytes (see Jeffrey and Vesk, 1997 for a review).

In order to analyze digested food separately from recently ingested food, the digestive tracts of bivalves were dissected into two parts. The proximal part of the gut was considered as the portion of the digestive tract between oesophagus and stomach whereas the distal part corresponded to the intestine between the digestive gland and the anus. The digestive glands of three oysters (mean dry weight $1 \mathrm{~g}$ ) were sampled and pooled in order to get enough material for spectrofluorometry analysis. Samples were kept at $-80{ }^{\circ} \mathrm{C}$ until extraction.

The proximal and distal part of the digestive tract were gently grounded with a freshly broken end of a glass rod in $6 \mathrm{ml}$ of a $0.1 \mathrm{M}$ phosphate buffer $(\mathrm{pH}=6.5)$ and extracted for 3 $\mathrm{h}$ at $4{ }^{\circ} \mathrm{C}$ (Lantoine and Neveux, 1997). The resulting mixture was filtered onto $25-\mathrm{mm} \mathrm{GF} /$ $\mathrm{F}$ filters and the filtrate was centifugated at $800 \mathrm{RCF}$ (relative centrifugal field) to remove any cellular fragments of the solution. Excitation and emission fluorescence spectra of the pink supernatant were recorded with a MPF-66 Perkin-Elmer spectrofluorometer after dilution in phosphate buffer looking for phycoerythrin and phycocyanin.

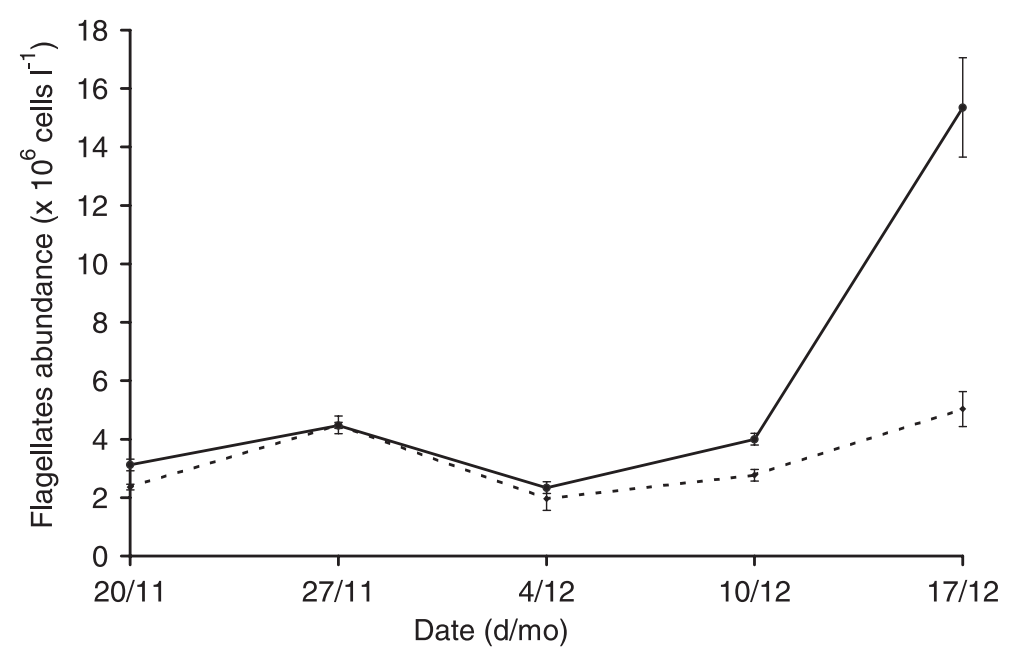

Fig. 2. Abundance of $>5 \mu \mathrm{m}$ autotrophic flagellates (expressed in $10^{6} \times$ cell $1^{-1}$ ) in oyster pond (dashed line) and control pond (solid line) during the 1998 winter season. Abundance data (mean \pm SD) were collected from three subsamples. 


\section{Results}

After 4 weeks of sequestration in the experimental pond, oysters were sampled for dry weight measurement and opened on December 17, 1998. While opening the oyster shells, a pink liquid running from the mouth into the palleal cavity of the bivalve was observed.

Identification of the pigment involved in this unusual color was performed by spectrofluorometry. Excitation and emission spectral properties were different in the two parts of the digestive tract. Excitation spectra of both fractions presented a clear peak at 544-545 $\mathrm{nm}$, but the pigment found in the proximal part showed an additional shoulder around 564 $\mathrm{nm}$ (Fig. 1). Additionally, the emission spectra for the proximal and distal parts of the digestive tract showed different peaks at 577 and $572 \mathrm{~nm}$, respectively. Both pigments, despite their differing spectral properties, are characteristics of Cryptomonad phycoerythrins. Examination of spectral absorption around $610 \mathrm{~nm}$ and emission at $650 \mathrm{~nm}$ revealed no phycocyanin in the samples.

At the beginning of sequestration, flagellates abundance was $3.2 \times 10^{6}$ cells $1^{-1}$ in the control oyster pond where $98 \%$ of the flagellates were autotrophs. During the third week, a bloom of phytoflagellates began and at the end of experimentation, their concentration was
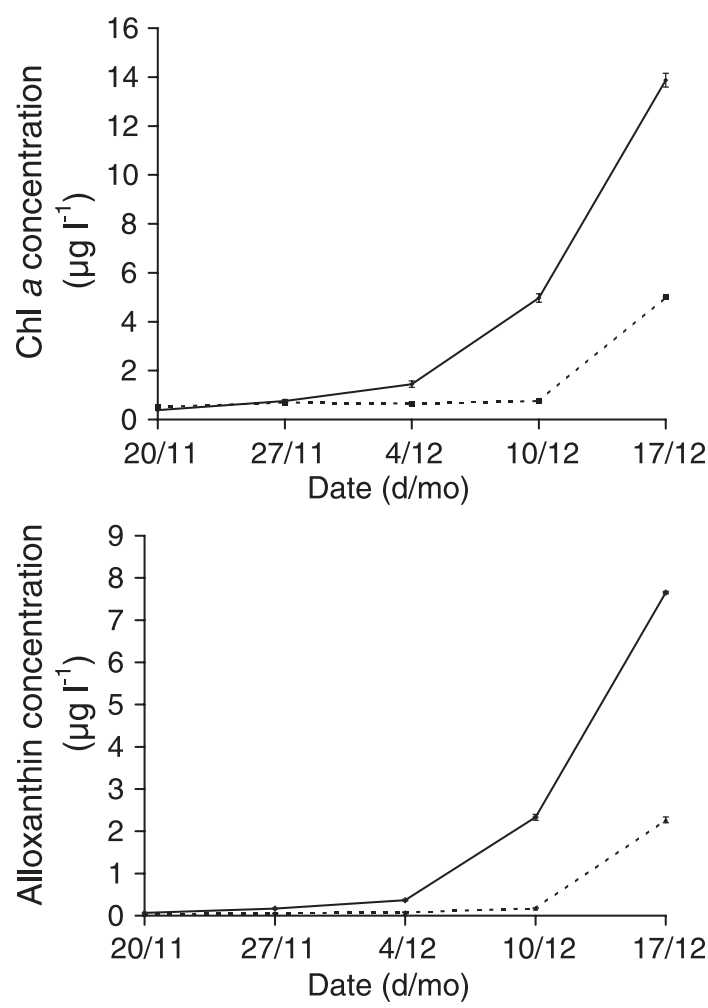

Fig. 3. Chlorophyll $a$ (Chl $a$ ) and alloxanthin concentrations (expressed in $\mu \mathrm{g}^{-1}$ ) in oyster pond (dashed line) and in control pond (solid line) during the 1998 winter season. 
$15 \pm 3.5 \times 10^{6}$ cells $1^{-1}$ (Fig. 2 ). In the oyster pond, the initial concentration was similar to those in control pond $\left(2.4 \times 10^{6}\right.$ flagellates $\left.1^{-1}\right) ; 98 \%$ of flagellates were phytoflagellates. A bloom of phytoflagellates appeared after the third week of sequestration, and at the end, phytoflagellates were ubiquitous in the oyster pond, but attained only $5 \pm 1 \times 10^{6}$ cells $1^{-1}$, a value three times lower than in the pond without oysters.

Pigment markers identified in both ponds were fucoxanthin (diatoms), peridinin (dinoflagellates), chlorophyll $b$ (green flagellates) and alloxanthin (cryptophytes). Temporal evolution of Chl $a$ and alloxanthin concentrations in the oyster and control ponds are shown in Fig. 3. Chlorophyll $a$ concentration varied from 0.4 to $14 \mu \mathrm{g}^{-1}$ in the control
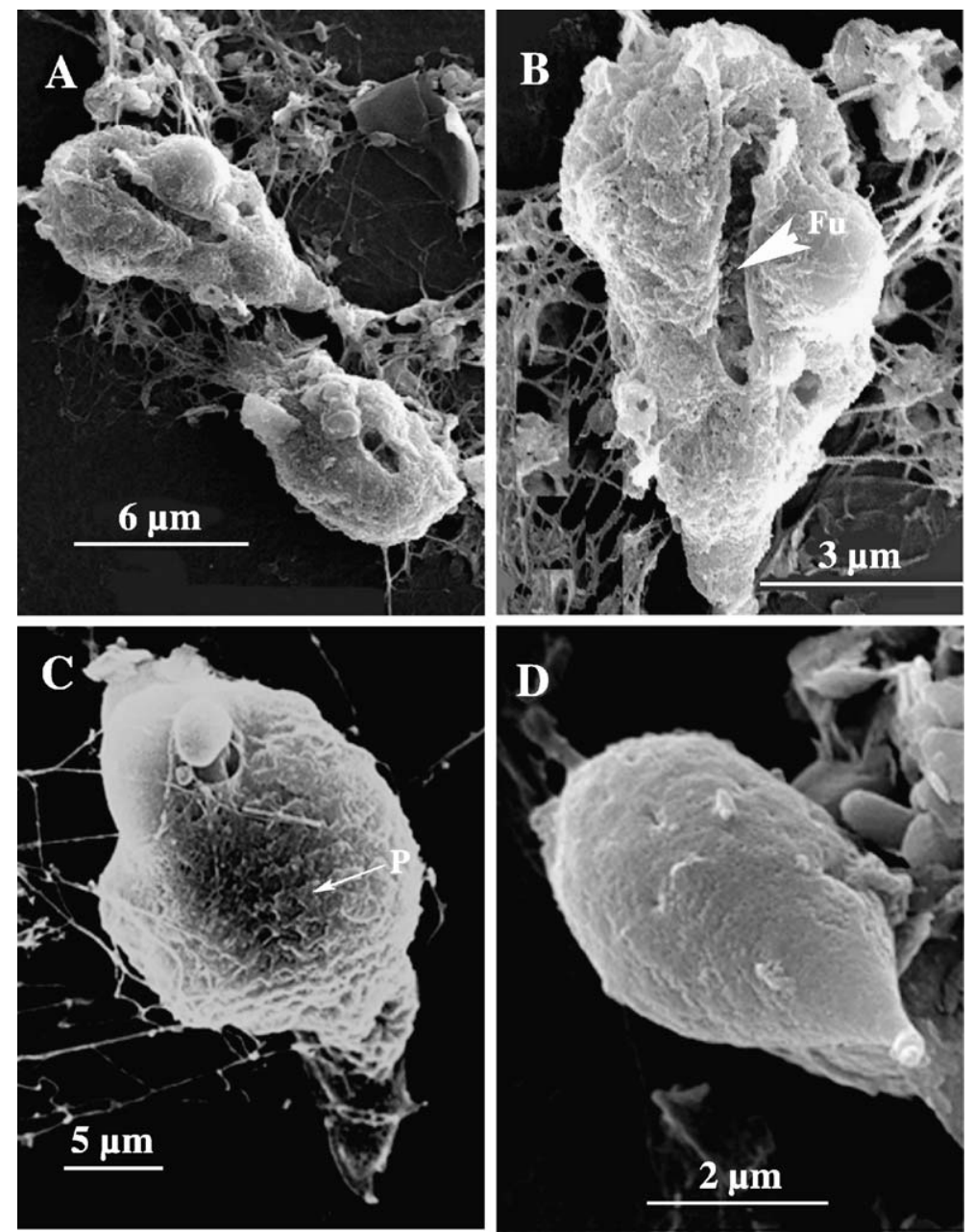

Fig. 4. (A-D) Critical point-dried cells of Plagioselmis prolonga examined by scanning electron microscopy. (A) Two cells in opposite position, embedded in mucilage. (B) Detail of a cell, showing the ventral sulcus (FU) and the tail. (C) A cell disrupted in its anterior part, with the chloroplast bulging outside. Periplastic plates (P) and trichocysts filaments visible. (D) Dorsal view of a cell with its bent tail, lying over detritic material. 
pond. Chl $a$ concentration in the oyster pond was lower than in the control pond and varied from 0.5 to $5.0 \mu \mathrm{g}^{-1}$. Marker pigments concentrations were very low $\left(<0.2 \mu \mathrm{g} 1^{-1}\right.$, data not shown) except for alloxanthin. Alloxanthin concentration ranged from 0.03 to $7.6 \mu \mathrm{g}$ $1^{-1}$ in the control pond and from 0.03 to $2.2 \mu \mathrm{g}^{-1}$ in the oyster pond (Fig. 3). After 2 weeks of experiment, an increase was observed in both Chl $a$ and alloxanthin concentrations in the control pond. The peak of Chl $a\left(14 \mu \mathrm{g}^{-1}\right)$ observed at the end of the experiment was associated to a bloom of cryptophytes $\left(7.6 \mu \mathrm{g} 1^{-1}\right.$ of alloxanthin). In contrast, Chl $a$ concentration remained constant in the oyster pond during the first 3 weeks. An increase in both Chl $a$ and alloxanthin was observed between the third and the fourth weeks of experiment in the oyster pond.

Detailed observation with the scanning electron microscope revealed crytpophycean cell types identified as Plagioselmis prolonga (Hill, 1992; Novarino et al., 1994) (Fig. 4A-D). The cells were often embedded in a mucilage made of ejected trichocysts (Fig. 4A-C), but a ventral sulcus was present and the tail was clearly visible (Fig. 4B). Partially overlapping scales were also present on the external face of the plasma membrane (Fig. 4C). The dorsal chloroplast was bulging and is pointing outside the cell on a disrupted part of the anterior end of a cell (Fig. 4C).

Rainfall, salinity, temperature and light data monitored during the experiment are shown in Fig. 5. The two experimental ponds were a shallow closed environment that was strongly affected by meteorological conditions. High variations in environmental conditions were
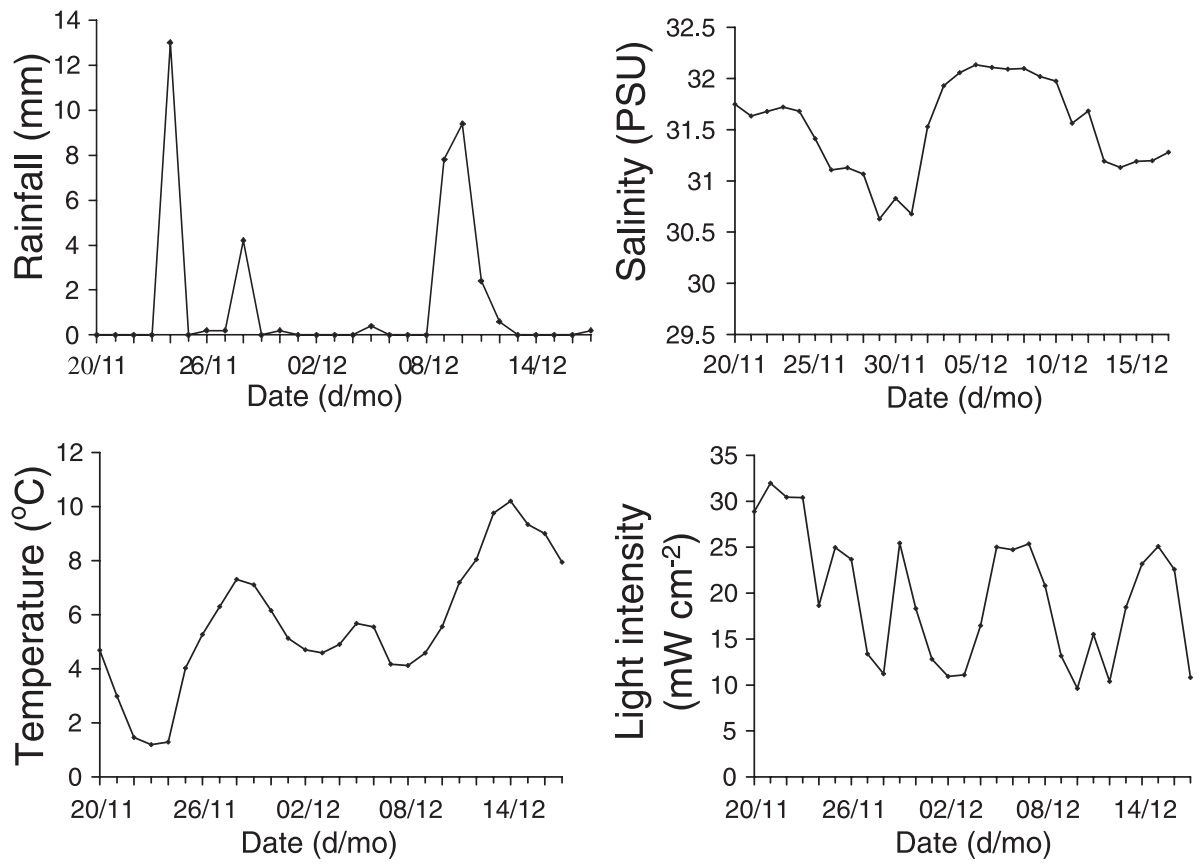

Fig. 5. Meteorological and hydrological parameters (rainfall, salinity, temperature and light) during the 1998 winter season. 
observed in both ponds during the 1998 winter season (Fig. 5). During the experimental period (November 20 to December 17), rainfall induced high variations in salinity (from 30.5 to $32 \mathrm{psu}$ ) and the temperature range was $8{ }^{\circ} \mathrm{C}$. Light conditions were highly variable too, ranging from 9 to $31 \mathrm{~mW} \mathrm{~cm}^{-2}$.

\section{Discussion}

Our results showed that the red coloration seen in the oysters was not linked to the presence of the dinoflagellate $P$. micans, both from pigment analyses and phytoplanktonic species found in the ponds.

Accumulation of phycoerythrin in mussels and scallops digestive glands has been previously described as due to M. rubrum and its cryptomonadal endosymbiont (Kat, 1984; Carver et al., 1996). Our microscopic observations of planktonic populations in the two ponds showed that the autotrophic ciliate M. rubrum was not present, eliminating this ciliate as the possible source of pigmentation.

Phycoerythrins are found in Cyanophytes, Rhodophytes and Cryptophytes, either free living or as symbionts. High concentrations of alloxanthin in the control pond clearly indicated the presence of abundant cryptophytes. These are considered as high nutritional value preys for zooplankton, as reviewed by Stewart and Wetzel (1986), but they are also selectively ingested and digested by filter-feeders bivalves (Shumway et al., 1985; Newell et al., 1989; Loret et al., 2000). In our experiment, cryptophytes were a possible food source for the oysters. An intense grazing on these algae was evidenced by important differences in cell counts (Fig. 2) and pigment concentrations in the two ponds (Fig. 3). Phycoerythrin accumulation in the digestive tract of the oysters was then explained by a high ingestion rate of these flagellates but raised the question of digestibility of this molecule. Phycoerythrin pigments having been released during cell lysis occurring in the digestive tract of the animal, it is likely that the pink liquid we observed running from the mouth into the palleal cavity of the oysters resulted from the partial digestion of cryptophytes.

Hill and Rowan (1989) reviewing Cryptomonad biliproteins showed that fluorescence emission characteristics are complementary to the excitation properties to distinguish the type and diversity of such molecules. Moreover, this diversity can partly be used in the taxonomy of Cryptomonad algae (Klaveness, 1985; Novarino et al., 1993). Among the several phycoerythrin types classically described, confusions about nomenclature of these pigments can be avoided by identifying them according to the wavelength of the maximum absorption in the visible spectrum as adopted by Hill and Rowan (1989).

By associating the excitation maximum $(545 \mathrm{~nm}$ ) with the shoulder at $564 \mathrm{~nm}$ in the excitation spectrum (Fig. 1), the pigment found in the proximal part of the digestive tract can be identified as the Cryptophyceae phycoerythin usually called $\mathrm{Cr}-\mathrm{PE}_{545}$. However, the emission maximum of this pigment at $577 \mathrm{~nm}$ is slightly different from the maximum values between 580 and $587 \mathrm{~nm}$ reported in the literature (Rowan, 1989; Wedemayer et al., 1992). Such a shift could be explained by the uncommon chemical conditions found in the digestive tract of the oyster. Similarly, the absence of shoulder at $564 \mathrm{~nm}$ in the excitation spectrum observed in the distal part of the digestive tract could be the result of alterations occurring during the digestive process. Glazer et al. (1982) have pointed out that many 
factors can affect the excitation and emission spectra of phycobiliproteins. Consequently, it is not surprising that the transit in the digestive tract could have modified the pigment structure and its spectral properties.

Cr- $\mathrm{PE}_{545}$ is a common and widely distributed biliprotein among marine genera. It is found in Rhodomonas, Rhinomonas, Plagioselmis, Proteomonas and various Cryptomonas species with uncertain taxonomic affinities (Hill and Rowan, 1989).

Red coloration of oyster C. gigas observed in December 1998 was related to the proliferation of the free-living cryptophyte $P$. prolonga. Marine cryptophytes are usually restricted to coastal and brackish water environments (Prézelin and Boczar, 1986) where they seasonally dominate nanoplankton communities (Pratt, 1959; Wasmund, 1994; Moline and Prézelin, 1996; Velikova et al., 1999; Casotti et al., 2000). Cryptophycean blooms have also been described in the open sea (Gieskes and Kraay, 1983; Buma et al., 1992). To our knowledge, this is the first time a cryptophytes bloom occurring in a coastal oyster pond along the French Atlantic coast is reported.

According to the literature, cryptophytes are particularly adapted to low temperature, low light and low salinity conditions (Stewart and Wetzel, 1986; Wasmund, 1994). Measurements of growth rates of phytoplankton under conditions of simulated turbulence have shown that only cryptophytes preferred calm conditions (Kohler, 1997). Results from mesocosm experiments were consistent with this observation and showed better development of cryptophytes when maintained under static conditions (Pinckney et al., 1999; Richardson et al., 2001). Interestingly, Gervais (1998) pointed out the importance of both cell motility and diel vertical migration on cryptophytes spatial distribution in a stratified water column (Lake Cisó, Spain).

As a consequence, we hypothesize that the initiation and continuation of the cryptophytes bloom in the oyster pond may have been related to both meteorological and hydrodynamical conditions present in the area.

There are a few photophysiological studies of cryptophytes, but it is known that their pigmentation can be light-regulated (Prézelin and Boczar, 1986) and a high content of phycoerythrin per cell can be expected in low light winter conditions. Environmental conditions in the oyster ponds could then explain the red coloration of the digestive gland after a high grazing of heavily pigmented cryptophytes by the oysters.

Thus, three major sources of red pigmentation in bivalves may occur in shellfish industry. In France, Mesodinium and Prorocentrum were already known to produce red tides and occasionally a red coloration of oysters (Lassus, 1988), but free-living cryptophytes have never been involved in the coloration of the digestive gland. Moreover, such phenomena have been observed during the summer time while the case reported here occurred during the winter season, a highly commercial period close to Christmas time and new year festivities. Because no data is available on cryptophytes abundance in open waters of this region, the frequency of such blooms cannot be estimated. Further investigations would be necessary in order to predict such events.

Although far from being toxic to human health, the red pigmentation of oysters is detrimental to shellfish commercialization. Carver et al. (1996) carried out depuration experiments of phycoerythrin in mussels. These authors pointed out that visualization of the red color was only possible with high pigment concentrations but that color disappearance was obtained after $48 \mathrm{~h}$ and full depuration of phycoerythrin needed 4-5 weeks. Short-term 
depuration in ponds devoid of red-pigment producing organisms is therefore suggested to eliminate this disadvantage.

\section{Acknowledgements}

We gratefully acknowledge M. Bréret for technical assistance and C. Vérity for HPLC analyses. This study was carried out with financial support from the Conseil Général de Charente-Maritime.

\section{References}

Begout-Anras, M.L., 1995. Demand-feeding behaviour of sea bass kept in ponds: diel and seasonal patterns, and influences of environmental factors. Aquacult. Int. 3 (3), 186-195.

Buma, A.G.J., Gieskes, W.W.C., Thomsen, H.A., 1992. Abundance of Cryptophyceae and chlorophyll $b$-containing organisms in the Weddell-Scotia confluence area in the spring of 1988. Polar Biol. 12, 43-52.

Caron, D.A., 1983. Technique for enumeration of heterotrophic and phototrophic nanoplankton, using epifluorescence microscopy, and comparison with other procedures. Appl. Environ. Microbiol. 46, 491-498.

Carver, C.E., Mallet, A.L., Warnock, R., Douglas, D., 1996. Red-coloured digestive glands in cultured mussels and scallops: the implication of Mesodinium rubrum. J. Shellfish Res. 15 (2), 191-201.

Casotti, R., Brunet, C., Aronne, B., Ribera d'Alcala, M., 2000. Mesoscale features of phytoplankton and planktonic bacteria in a coastal area as induced by external water masses. Mar. Ecol. Prog. Ser. 195, $15-27$.

Dupuy, C., Le Gall, S., Hartmann, H.J., Bréret, M., 1999. Retention of ciliates and flagellates by the oyster Crassostrea gigas in French Atlantic coastal ponds: protists as a trophic link between bacterioplankton and benthic suspension-feeders. Mar. Ecol. Progr. Ser. 177, 165-175.

Dupuy, C., Pastoureaud, A., Ryckaert, M., Sauriau, P.G., Montanié, H., 2000. Impact of the oyster Crassostrea gigas on the microbial community in Atlantic coastal ponds near La Rochelle. Aquat. Microb. Ecol. 22, $227-242$.

Gervais, F., 1998. Ecology of cryptophytes coexisting near a freshwater chemocline. Freshw. Biol. 39, 61-78.

Gieskes, W.W.C., Kraay, G.W., 1983. Dominance of Cryptophyceae during the phytoplankton spring bloom in the central North Sea detected by HPLC analysis of pigments. Mar. Biol. 75, 179-185.

Glazer, A.N., West, J.A., Chan, C., 1982. Phycoerythrins as chemotaxonomic markers in red algae: a survey. Biochem. Ecol. 10, 203-215.

Gustafson Jr., D.E., Stoecker, D.K., Johnson, M.D., Van Heukelem, W.F., Sneider, K., 2000. Cryptophyte algae are robbed of their organelles by the marine ciliate Mesodinium rubrum. Nature 405, 1049-1052.

Haas, L.W., 1982. Improved epifluorescence microscopy for observing planktonic microorganisms. Ann. Inst. Oceanogr. 58, 261-266.

Hata, M., Hata, M., 1982. Isolation and properties of peridinin-chlorophyll $a$-protein complex from the brickred-colored oyster, Crassostrea gigas. Comp. Biochem. Physiol. 72B (4), 631-635.

Hata, M., Abe, S., Hata, M., 1982a. Occurrence of peridinin-chlorophyll $a$-protein complex in red tide dinoflagellate Prorocentrum micans. Bull. Jpn. Soc. Sci. Fish. 48, 459-461.

Hata, M., Hata, M., Nakamura, K., Fujiwara, H., 1982b. Brick-red coloration of oyster Crassostrea gigas. Bull. Jpn. Soc. Sci. Fish. 48 (7), 975-979.

Hill, D.R.A., 1992. Plagioselmis prolonga Butcher (Cryptophyceae). Baltic sea phytoplankton identification sheet No. 8. Ann. Bot. Fenn. 29, 165-166.

Hill, D.R.A., Rowan, K.S., 1989. The biliproteins of the Cryptophyceae. Phycologia 28, 455-463.

Jeffrey, S.W., Vesk, M., 1997. Introduction to marine phytoplankton and their pigment signatures. In: Jeffrey, S.W., Mantoura, R.F.C., Wright, S.W. (Eds.), Phytoplankton Pigments in Oceanography. UNESCO, Paris, France, pp. $37-84$. 
Kat, M., 1984. "Red" oysters (Ostrea edulis L.) caused by Mesodinium rubrum in Lake Grevelingen. Aquaculture $38,375-377$.

Klaveness, D., 1985. Classical and modern criteria for determining species of Cryptophyceae. Bull. Plankton Soc. Jpn. 32, $111-128$.

Kohler, J., 1997. Measurement of in situ growth rate of phytoplankton under conditions of simulated turbulence. J. Plankton Res. 19, 849-862.

Lantoine, F., Neveux, J., 1997. Spatial and seasonal variations in abundance and spectral characteristics of phycoerythrins in the tropical northeastern Atlantic Ocean. Deep-Sea Res. 44, 223-246.

Lassus, P., 1988. Plancton toxique et plancton d'eaux rouges sur les côtes européennes. IFREMER, Plouzané, France. $111 \mathrm{pp}$.

Loret, P., Pastoureaud, A., Bacher, C., Delesalle, B., 2000. Phytoplankton composition and selective feeding of the pearl oyster Pinctada margaritifera in the Takapoto lagoon (Tuamotu Archipelago, French Polynesia): in situ study using optical microscopy and HPLC pigment analysis. Mar. Ecol. Prog. Ser. 199, 55-67.

Moline, M.A., Prézelin, B.B., 1996. Long-term monitoring and analyses of physical factors regulating variability in coastal Antarctic phytoplankton biomass, in situ productivity and taxonomic composition over subseasonal, seasonal and interannual time scale. Mar. Ecol. Prog. Ser. 145, 143-160.

Newell, C.R., Shumway, S.E., Cucci, T.L., Selvin, R., 1989. The effects of natural seston particle size and type on feeding rates, feeding selectivity and food resource availability for the mussel Mytilus edulis L., 1758 at bottom culture sites in Maine. J. Shellfish Res. 8, 187-196.

Novarino, G., Lucas, F.L.S., Lucas, I.A.N., 1993. Some proposals for a new classification system of Cryptophyceae. Bot. J. Linn. Soc. 111, 3-21.

Novarino, G., Lucas, I.A.N., Morral, S., 1994. Observations on the genus Plagioselmis (Cryptophyceae). Cryptogam. Algol. 15 (2), 87-107.

Pinckney, J.L., Paerl, H.W., Harrington, M.B., 1999. Responses of the phytoplankton community growth rate to nutrient pulses in variable estuarine environments. J. Phycol. 35, 1455-1463.

Pratt, D.M., 1959. The phytoplankton of Narragansett Bay. Limnol. Oceanogr. 4 (4), $425-440$.

Prézelin, B.P., Boczar, B.A., 1986. Molecular bases of cell absorption and fluorescence in phytoplankton: potential applications to studies in optical oceanography. In: Round, F.E., Chapman, D.J. (Eds.), Progress in Phycological Research, vol. 4. BioPress, Bristol, pp. 349-465.

Prézelin, B.B., Haxo, F.T., 1976. Purification and characterization of peridinin-chlorophyll $a$-proteins from the marine dinoflagellaes Glenodinium sp and Gonyaulax polyedra. Planta (Berlin) 128, 133-141.

Richardson, T.L., Pinckney, J.L., Paerl, H.W., 2001. Responses of estuarine phytoplankton communities to nitrogen form and mixing using microcosm bioassays. Estuaries 24 (6A), 828-839.

Rowan, K.S., 1989. Photosynthetic Pigments of Algae. Cambridge Univ. Press, Cambridge, UK. 334 pp.

Sherr, E.B., Caron, D.A., Sherr, B.F., 1994. Staining of heterotrophic protists for visualisation via epifluorescence microscopy. In: Kemp, P.F., Sherr, E.B., Cole, J.J. (Eds.), Handbook of Methods in Aquatic Microbial Ecology. Lewis Publishers, Boca Raton, pp. 213-227.

Shumway, S.E., Cucci, T.L., Newell, R.C., Yentsch, C.M., 1985. Particle selection, ingestion and absorption in filter-feeding bivalves. J. Exp. Mar. Biol. Ecol. 91, 77-92.

Stewart, A.J., Wetzel, R.G., 1986. Cryptophytes and other microflagellates as couplers in planktonic community dynamics. Arch. Hydrobiol. 106 (1), 1-19.

Velikova, V.N., Moncheva, S., Petrova, D., 1999. Phytoplankton dynamics and red tides (1987-1997) in the Bulgarian Black sea. Water Sci. Technol. 39 (8), 27-36.

Ward, J.E., Levington, J.S., Shumway, S.E., Cucci, T., 1997. Site of particle selection in a bivalve mollusc. Nature 390, 131-132.

Wasmund, N., 1994. Phytoplankton periodicity in a eutrophic coastal water of the Baltic sea. Int. Rev. Gesamten Hydrobiol. 79 (2), 259-285.

Wedemayer, G.J., Kidd, D.G., Wemmer, D.E., Glazer, A.N., 1992. Phycobilins of Cryptophycean algae. Occurrence of dihydrobiliverdin and mesobiliverdin in Cryptomonad biliproteins. J. Biol. Chem. 267, 7315-7331.

Wright, S.W., Jeffrey, S.W., Mantoura, R.F.C., Llewellyn, C.A., Bjornland, T., Repeta, D., Welschmeyer, N., 1991. Improved HPLC method for analysis of chlorophylls and carotenoids from marine phytoplankton. Mar. Ecol. Progr. Ser. 77, 183-196. 